\title{
PALYNOMORPHS FROM ABRA LÍMITE, ZENTA RANGE, EASTERN CORDILLERA, NORTHWESTERN ARGENTINA
}

\author{
SOL NOETINGER \& MERCEDES DI PASQUO \\ CONICET, Departamento de Geología, Universidad de Buenos Aires, Intendente Güiraldes 2160 (C1428EGA). \\ Ciudad Autónoma de Buenos Aires, Argentina.snoetinger@gl.fcen.uba.ar, medipa@gl.fcen.uba.ar
}

\begin{abstract}
This study presents the first Devonian palynological record in the Zenta Range in Eastern Cordillera, Argentina. Two associations were recognized on the basis of differences in palynomorphs and palynofacies. The palynoassemblage AL1, from the lower part of the outcrop, is characterized by chitinozoans, such as Cingulochitina sp. cf. C. serrata and Hoegisphaera sp. cf. H. glabra, accompanied by a few species of phytoplankton, which suggests the Lochkovian s. $l$., and palynofacies indicate a marine paleoenvironment. The appearance of Diboliporites farraginis in the palynoassemblage AL2 suggests a Middle Devonian. The concurrence of some fresh or brackish water taxa, sporomorphs and very few acritarchs, denotes littoral conditions in this part of the succession. The transgression for the Early Devonian is recorded in AL1.
\end{abstract}

Key words: palynology, Devonian, palaeonvironment, northwestern Argentina.

\begin{abstract}
RESUMO - Apresenta-se o primeiro registro palinológico devoniano da Faixa Zenta, Cordilheira Oriental, Argentina. Com base nas diferenças qualitativas e palinofácies duas associações foram reconhecidas. A associação palinológica AL1, ocorrente na parte inferior do afloramento, é caracterizada principalmente por quitinozoários, como Cingulochitina sp. cf. C. serrata e Hoegisphaera sp. cf. H. glabra, com o registro subordinado de táxons fitoplanctônicos permite posicionamento no Lochkoviano $s$. $l$, com características palinofaciológicas de ambiente marinho. O registro de Diboliporites farraginis na associação palinológica AL2 sugere correspondência com o Devoniano Médio. A ocorrência de determinados táxons de água doce ou salgada juntamente com esporomorfos e acritarcos, denota condições ambientais costeiras para a parte superior da sucessão. O marco transgressivo proposto para o Devoniano inicial, relacionado à origem da expansão da bacia sedimentar, está registado na associação palinológica AL1.
\end{abstract}

Palavras-chave: palinologia, Devoniano, paleoambientes, noroeste da Argentina.

\section{INTRODUCTION}

The Zenta Range (Figure 1) covers a surface of over $15,000 \mathrm{~km}^{2}$ in the northern provinces of Salta and Jujuy, Argentina, reaching up to 5,000 $\mathrm{m}$ above sea level. In Jujuy, it comprises one of the main mountain chains on the east flank of the Eastern Cordillera. Several localities have been surveyed stratigraphically and palynologically (Vergel et al., 2008a). This study presents a detailed palynological analysis recovered from a succession at Abra Límite locality $\left(23^{\circ} 10.858^{\prime}\right.$ $\left.\mathrm{S}, 65^{\circ} 0.343^{\prime} \mathrm{W}\right)$. This locality, begins over a polimictic conglomerate with $\mathrm{Fe}$ nodules and comprises heterolithic facies at the base followed by thick packages of sandstones interbedded with less thick beds of conglomerates and shales to fine-grained sandstones ( $\mathrm{ca} .250 \mathrm{~m}$ thick) and finishes with a greenish-grey diamictitic bed ( $c a .50 \mathrm{~m}$ thick) in unconformable contact (Figure 2).

The stratigraphic distribution of the species is analysed and compared with their global ranges to assess the age and correlation of the assemblage. Palynofacies and taphonomical features are considered in order to improve previous palaeoenvironmental interpretations.

\section{STRATIGRAPHY}

The stratigraphic units of the Late Silurian to Devonian rocks from northern Argentina and southern Bolivia have been assigned to supersequence hierarchies by Starck (1995, 1999). This includes a Silurian-Jurassic tectonic-stratigraphic interval that is divided into two units separated by a regional unconformity at the end of the Devonian. In the first SilurianDevonian unit, the Cinco Picachos, Las Pavas and Aguaragüe Supersequences are characterized by stacked, kilometre-scale, coarsening-upward shale and sandstone facies bounded by first order flooding surfaces. Under this scheme, at the Eastern Cordillera, the Baritú and Porongal formations are part of the Cinco Picachos Supersequence. The lower Baritú Formation comprises a sequence of coarsening-upward facies with a strong cyclicity. These facies become more arenaceous with medium scale crossbeding at the top. Several invertebrates, like Australocoelia tourteloti, Australospirifer antarcticus and trilobites have been found in this unit, which indicates the Early Devonian (Cuerda \& Baldis, 1971; Turner, 1972). The Porongal Formation consists of conglomerates with interbedded mudstones. The Las Pavas Supersequence, at 
the Eastern Cordillera, is constituted by the Pescado and Cerro Piedras formations, the former composed of crossbedding fine-grained sandstones with interbedded grey to dark grey carbonaceous shales. The Cerro Piedras unit has the highest fossil content with plant remains, trilobites, pelecypods, brachiopods and gastropods. Begining with a polimictic conglomerate and following upward by dark green to black shales (Padula et al., 1967; Aceñolaza et al., 1999). Padula et al. (1967) correlated the Cerro Piedras shales with the Icla Formation. This succesion ends with an unconformable surface where Upper Palaeozoic sediments are deposited (Padula et al., 1967; Cuerda \& Baldis, 1971; Starck et al., 1993a,b).

\section{MATERIAL AND METHODS}

Seven samples (BAFC-Pl 2086 to 2092) were collected from a succession, of dark grey laminated fine pelites interbedded with coarse sandstones and is considered possibly Devonian (G. Aceñolaza, pers. comm.). The sample from the diamictite at the top (BAFC-Pl 2093) was studied by di Pasquo \& Vergel (2008) yielding a microflora akin to the Pennsylvanian. The base of the succession, considered possibly Ordovician, is the subject of this study.

Standard palynological methods were performed to obtain organic residues from the samples. They were crushed and treated first with hydrochloric and then with hydrofluoric acid to remove carbonate, silica and silicates, respectively. The residue was sieved with a $25 \mu \mathrm{m}$ mesh and finally mounted on slides with glycerine jelly.
The identification of palynomorphs was undertaken using both Leitz Orthoplan and Nikon Eclipse 80i trinocular transmitted light microscopes, with x1,000 maximum magnification. The photomicrographs were obtained with Motic (2.0 megapixels) and Pax-it (3.1 megapixels) video cameras and the illustrations are labelled with BAFC-Pl numbers followed by an England Finder reference. The studied samples are deposited in the Department of Geology, Faculty of Natural and Pure Sciences, University of Buenos Aires.

\section{RESULTS}

\section{Composition of the assemblages and palaeoenvironmental considerations}

The whole assemblage, recovered along the investigated interval, is composed of relatively poorly-preserved species (Appendix 1) representing diverse palynological groups such as cryptospores and trilete spores, microplankton including acritarchs and Prasinophycean, other Chlorophycean algae like Quadrisporites, and chitinozoans. The thermal maturity (TAI) varies between 2 and 3 according to the scale of Utting et al. (in Utting \& Wielens, 1992). Two assemblages are defined based on the presence of key taxa and palynofacies differences (Figures 2-3).

Palynoassemblage AL1. This assemblage comprises five productive samples of clay/siltstone beds obtained from the basal to medium portion of the outcrop (Figure 2). It is composed mostly of marine elements (86\%) mainly represented by chitinozoans (Figure 3). The biodiversity is

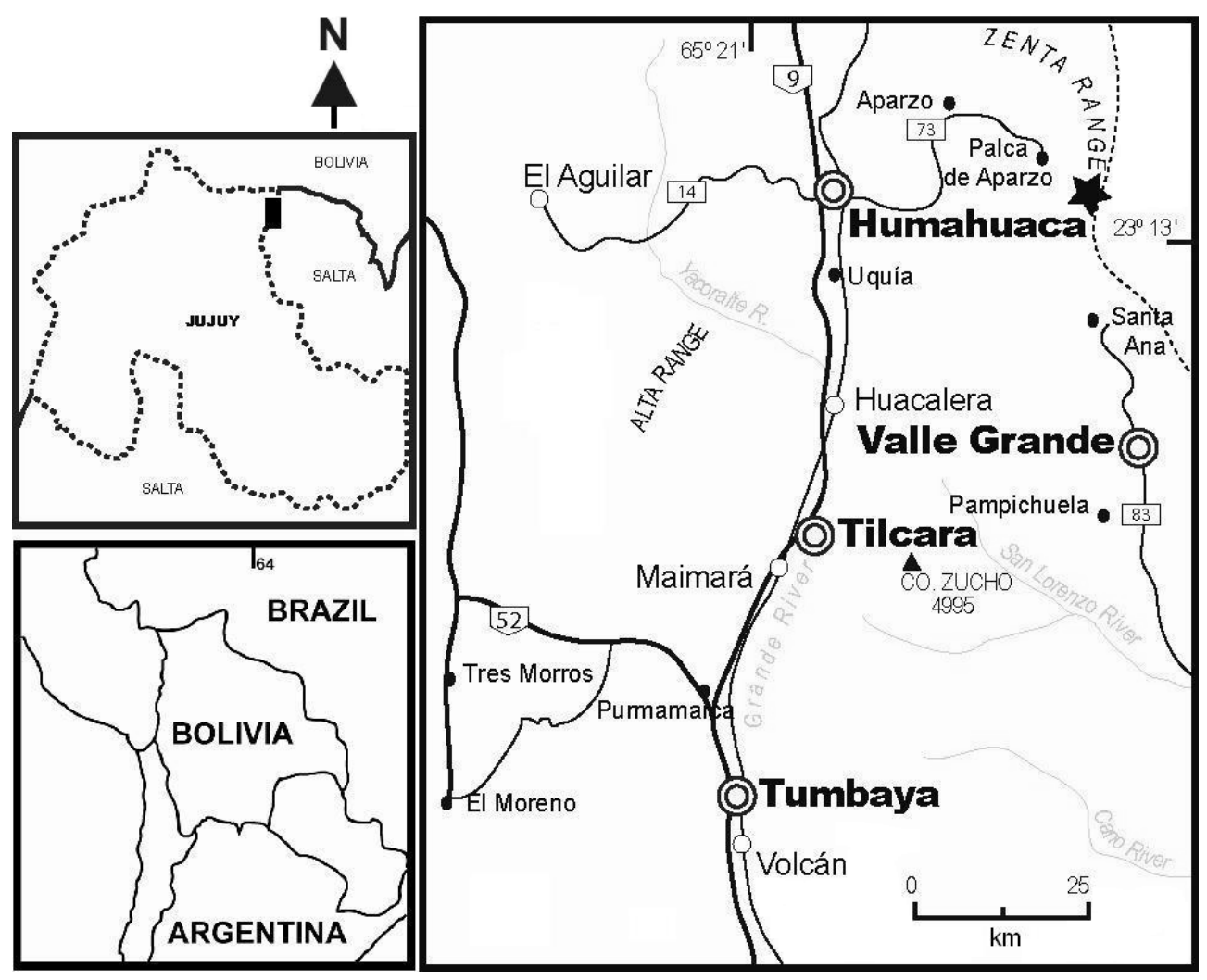

Figure 1. Map of northwestern Argentina, showing the location of the study area. 
relatively high in comparison with the palynoassemblage AL2. The preservation is variable, from fairly good to quite poor, so the identification of many palynomorphs was rather difficult. The palynofacies is characterized by a high concentration of finely particulate amorphous organic matter (AOM) and a lower proportion of gelified material. A marine depocentre is supported based on the qualitative composition of the assemblage together with the palynofacies and lithology characters.

Palynoassemblage AL2. This assemblage is represented by the last $80 \mathrm{~m}$ of the upper part below the contact with the diamictite. It is comprised of predominantly continental elements (97\%), including spores (65\%) and fresh to brackish water microplankton characterized by species of Quadrisporites (32\%). The biodiversity decreases with respect to the underlying assemblage and taxa, such as acritarchs and chitinozoans, are rare to absent, respectively (Figure 3). Dark cuticle composes the majority of the phytodebris. It is noteworthy that the brackish specimens, like Quadrisporites spp., ?coenobial algae, and only one spore tetrad (Figure 4M) occur in the uppermost sample (BAFC-Pl 2092, see Figures 2-3).

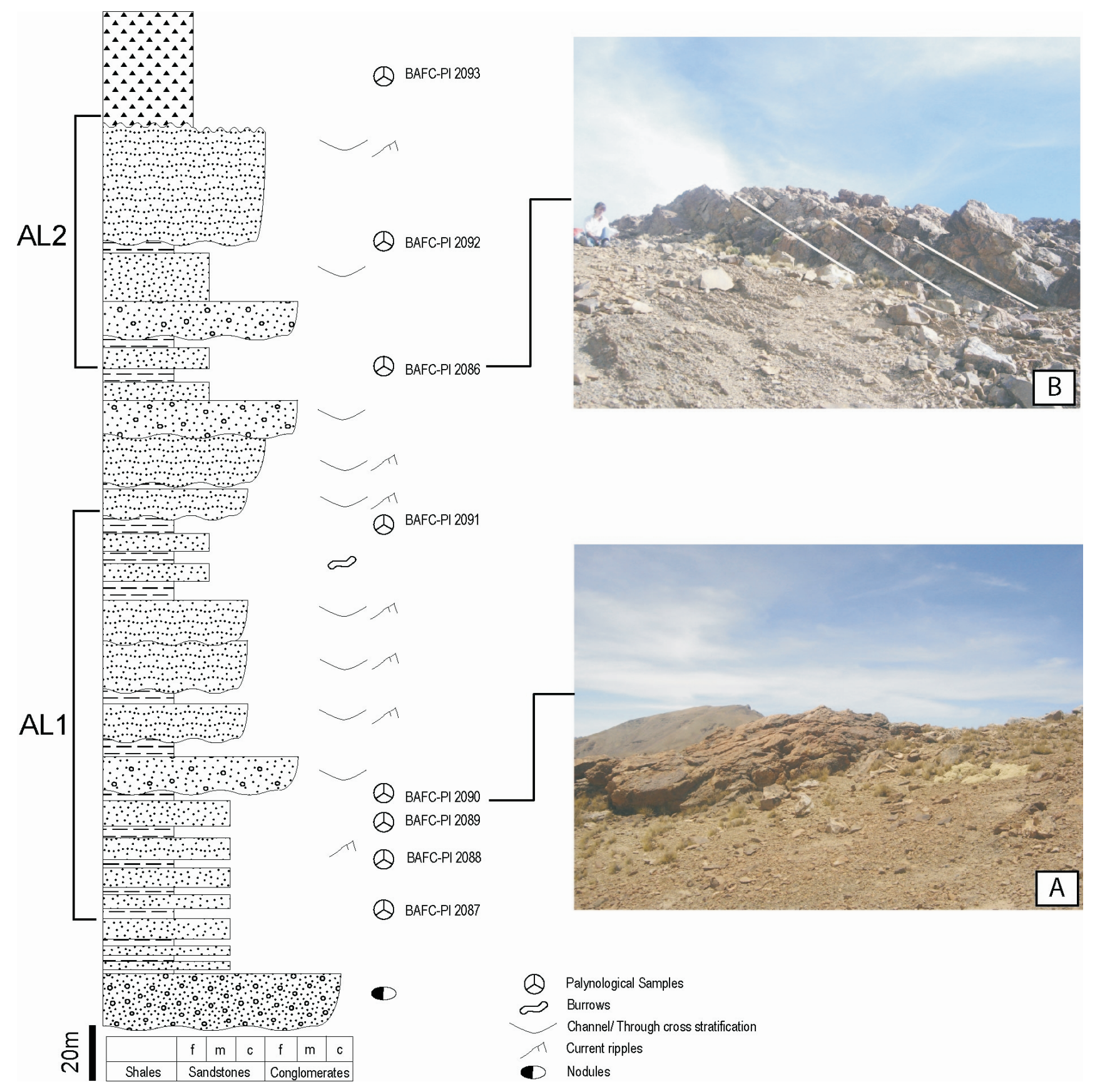

Figure 2. Stratigraphic section from the Abra Límite locality with the position of the studied samples, quoted with the BAFC-PI acronym. A, channel over the fine sandstones and shale from where the sample BAFC-PI 2090 was collected; B, channel erosive contact over fine sandstones and shales and lateral accretion surfaces. Abbreviations: AL1, palynoassemblage 1; AL2, palynoassemblage 2. 
The palynofacies variations support palaeoenvironmental changes during the deposition of the succession. It is likely that the low proportion of marine elements, the high occurrence of miospores and the appearance of Quadrisporites spp. in the AL2 are evidence of littoral to brackish palaeoenvironments developed in this region.

\section{Age assessment and correlation}

Palynoassemblage AL1. The presence of Hoegisphaera sp. cf. H. glabra ranging from the Upper Lochkovian and to the Givetian (see Grahn et al., 2003; Grahn, 2005), suggests a Lochkovian (?Late Lochkovian) age, supported by the cooccurrence of species with affinity to Angochitina chlupaci, characteristic of the Lochkovian strata for the Northern Hemisphere such as in Canada (Achab \& Asselin, 1993; Burden et al., 2002), Czech Republic (Paris et al., 1981; Fatka et al., 2003), Bulgaria (Lakova, 1993), the Balkan Peninsula (Haydoutov \& Yanev, 1997), Austria (Priewalder, 2000) and Romania (Vaida \& Verniers, 2005, 2006); Ancyrochitina tomentosa and Cingulochitna serrata which mark the upper part of the A. chlupaci-A. tomentosa Interval zone ranged as Middle-Upper Lochkovian (Lakova, 1993). The fact that there are not any species restricted to the late Silurian also supports a Lochkovian s.l. for AL1.

Palynoassemblage AL2. The age of this assemblage would be delimited by the appearance of Dibolisporites farraginis, a species that is noted from the Upper Eifelian to the Lower Frasnian (see di Pasquo, 2007). This species is accompanied by Quadrisporites spp. and several other species left in open nomenclature due to the poor preservation. Thus there is a paucity of diagnostic elements which reduces the confidence of the age assignment for AL2. On the other hand, the diamictite, dated as Pennsylvanian (di Pasquo \& Vergel, 2008), supports the proposition of a Middle Devonian age for AL2; Vergel et al. (2008b) indicate a Late Devonian to Mississippian hiatus at this locality.

\section{CONCLUSIONS}

The recovered palynological material provides valuable stratigraphic and palaeonvironmental information for the stratigraphy previously established without fossils for the Zenta Range in northwestern Argentina. The stratigraphic distribution of taxa together with palynofacies differences support the recognition of two associations. The palynoassemblage AL1 is dated as Lochkovian s.l. based on the chitinozoans primarily, whilst the appearance of Dibolisporites farraginis in the palynoassemblage AL2 suggests a Middle Devonian age.

The lower part of the outcrop here studied bearing the AL1, is likely attributed to the Baritú and Porongal formations (Cinco Picachos Supersequence) in agreement with Starck (1999), although the presence of chitinozoans and other phytoplankton species enable us to reinterpret it as a marine palaeoenvironment. Instead, the upper part of this outcrop bearing the AL2 agrees with the littoral to proximal shelf Pescado and Cerro Piedras formations (Las Pavas Supersequence).

The proposed transgression for the Early Devonian, which marks the origin of the basin expansion, is registered in the palynoassemblage AL1 based on the presence of several marine taxa. In contrast, the abundance of some brackish elements such as Quadrisporites variabilis, Quadrisporites granulatus, ?coenobial algae and continental sporomorphs, the scarcity of acritarchs and the lack of chitinozoans in the palynoassemblage AL2 denote a littoral depocenter in the upper section of the studied outcrop.

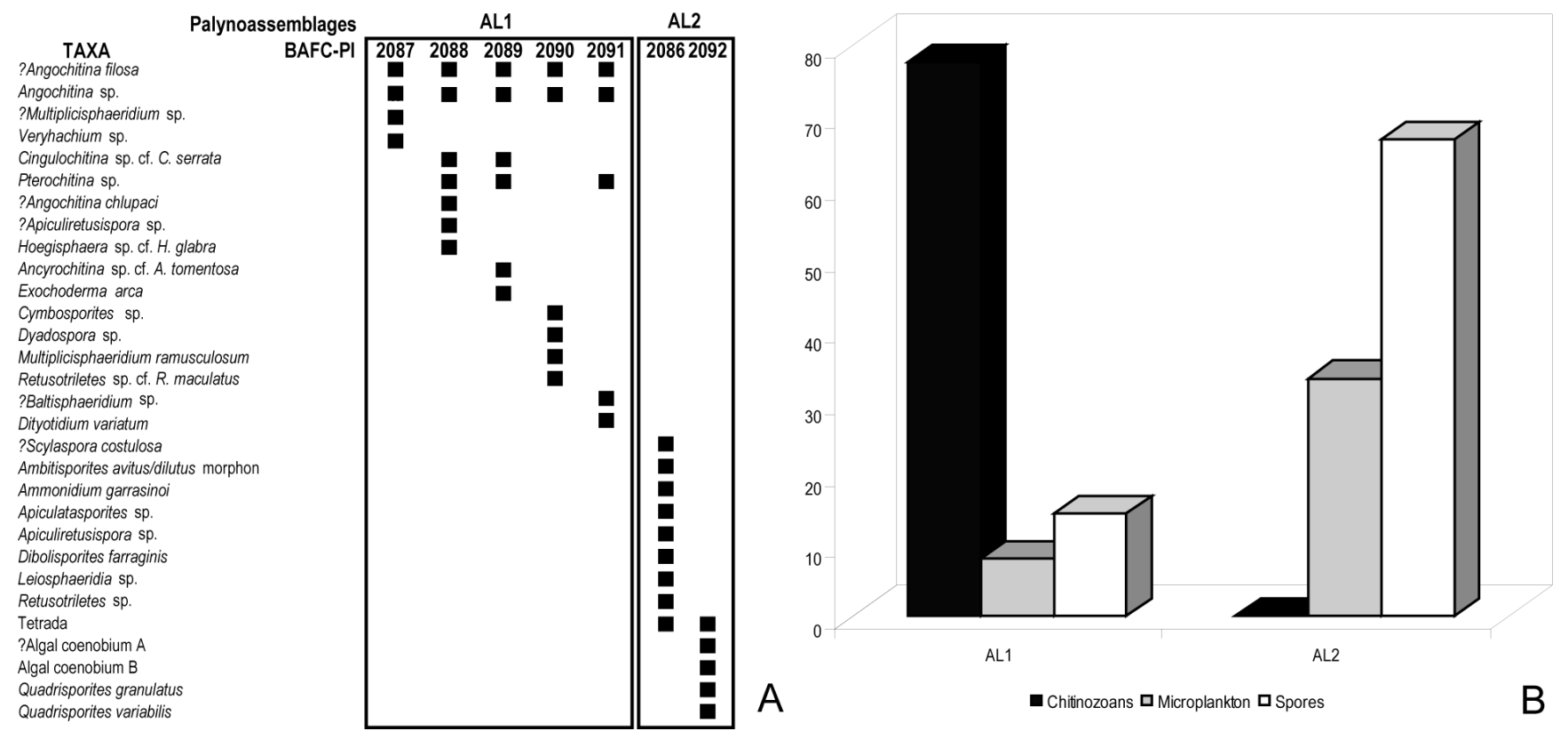

Figure 3. A, distribution of the recognized species in each one of the assemblages; B, statistical distribution of the main groups conforming the palynoassemblages AL1 and AL2. 


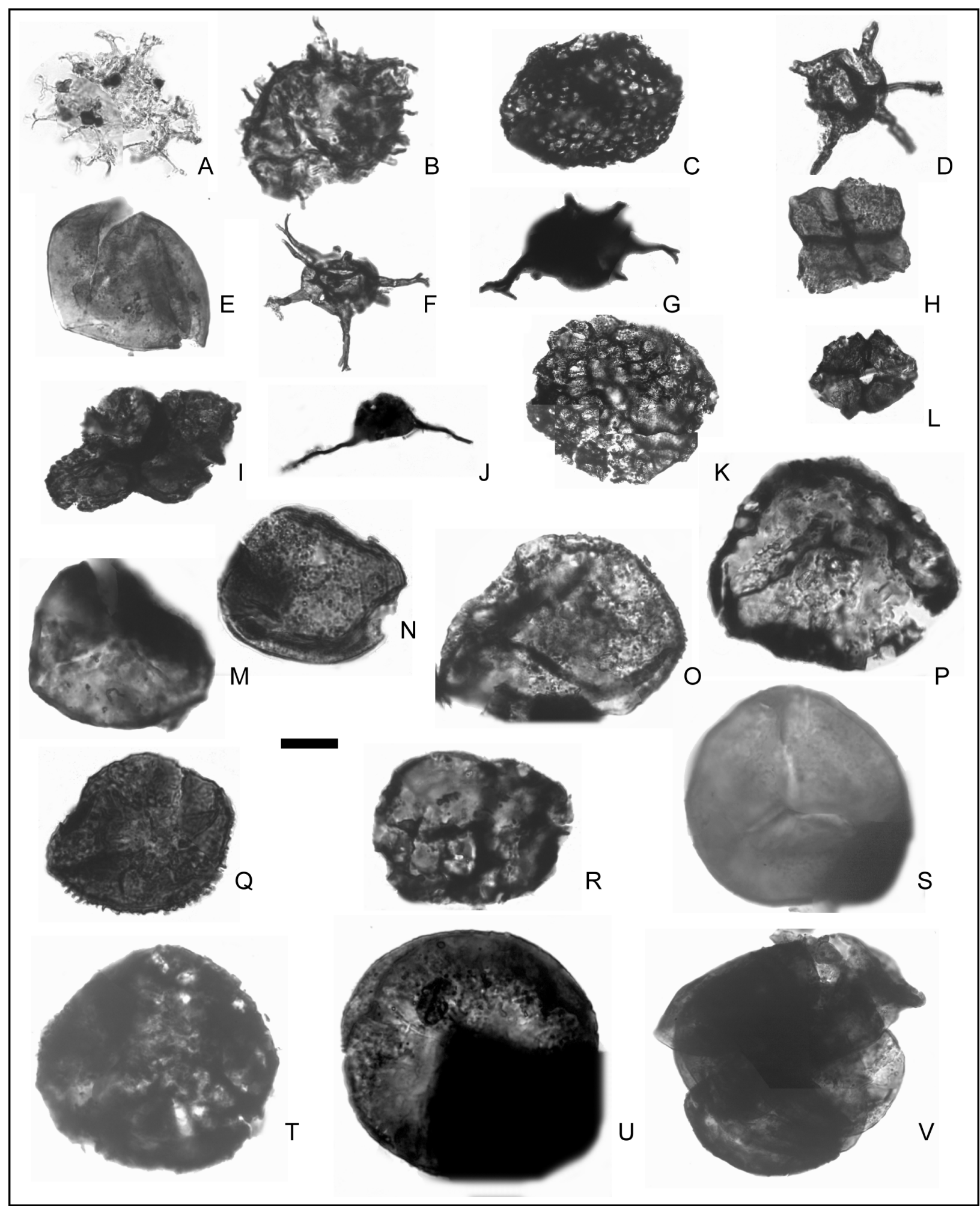

Figure 4. A, Ammonidium garrasinoi (BAFC-PI 2086(1), EF: Y43/1); B, Baltisphaeridium? sp. (BAFC-PI 2091(1), EF: F48); C, Dictyotidium variatum (BAFC-PI 2091(1), EF: V52/3); D, Exochoderma arca (BAFC-PI 2089(1), EF: T49/3); E, Leiosphaeridia sp. (BAFC-PI 2086(1), EF: C26); F, Multiplicisphaeridium ramusculosum (BAFC-PI 2091(1), EF: B48/2); G, ?Multiplicisphaeridium sp. (BAFC-PI 2087(1), EF: C32/2); H, Quadrisporites granulatus (BAFC-PI 2092(1), EF: X46); I, Quadrisporites variabilis (BAFC-PI 2092(1), EF: V38/1); J, Veryhachium sp. (BAFC-PI 2087(1), EF: C41); K, ?Algal coenobium A (BAFC-PI 2092(1), EF: W34/1); L, Algal coenobium B (BAFC-PI 2092(1), EF: Z38/3); M, Ambitisporites avitus/dilutus morphon BAFC-PI 2086(1), EF: U51/1); N, Apiculatasporites sp. (BAFC-PI 2086(1), EF: C25/1); O, Apiculiretusispora sp. (BAFC-PI 2086(1), EF: E25/3); P, Cymbosporites sp. (BAFC-PI 2090(1), EF: O31/2); Q, Dibolisporites farraginis (BAFC-PI 2086(1), EF: B27/2); R, Dyadospora sp.(BAFC-PI 2090(1), EF: S26); S, Retusotriletes sp. (BAFC-PI 2086(1), EF: G55/3); T, Retusotriletes sp. cf. R. maculatus (BAFC-PI 2090(1), EF: Q23/3); U, ? Scylaspora costulosa (BAFC-PI 2086(1), EF: E40); V, Tetrad (BAFCPI 2086(1), EF: Z27/2). Scale bars: A, C-J, V = $20 \mu \mathrm{m}$.; $B=10 \mu \mathrm{m}$; $\mathrm{K}, \mathrm{L}=35 \mu \mathrm{m}$.; $\mathrm{M}-\mathrm{U}=15 \mu \mathrm{m}$. 


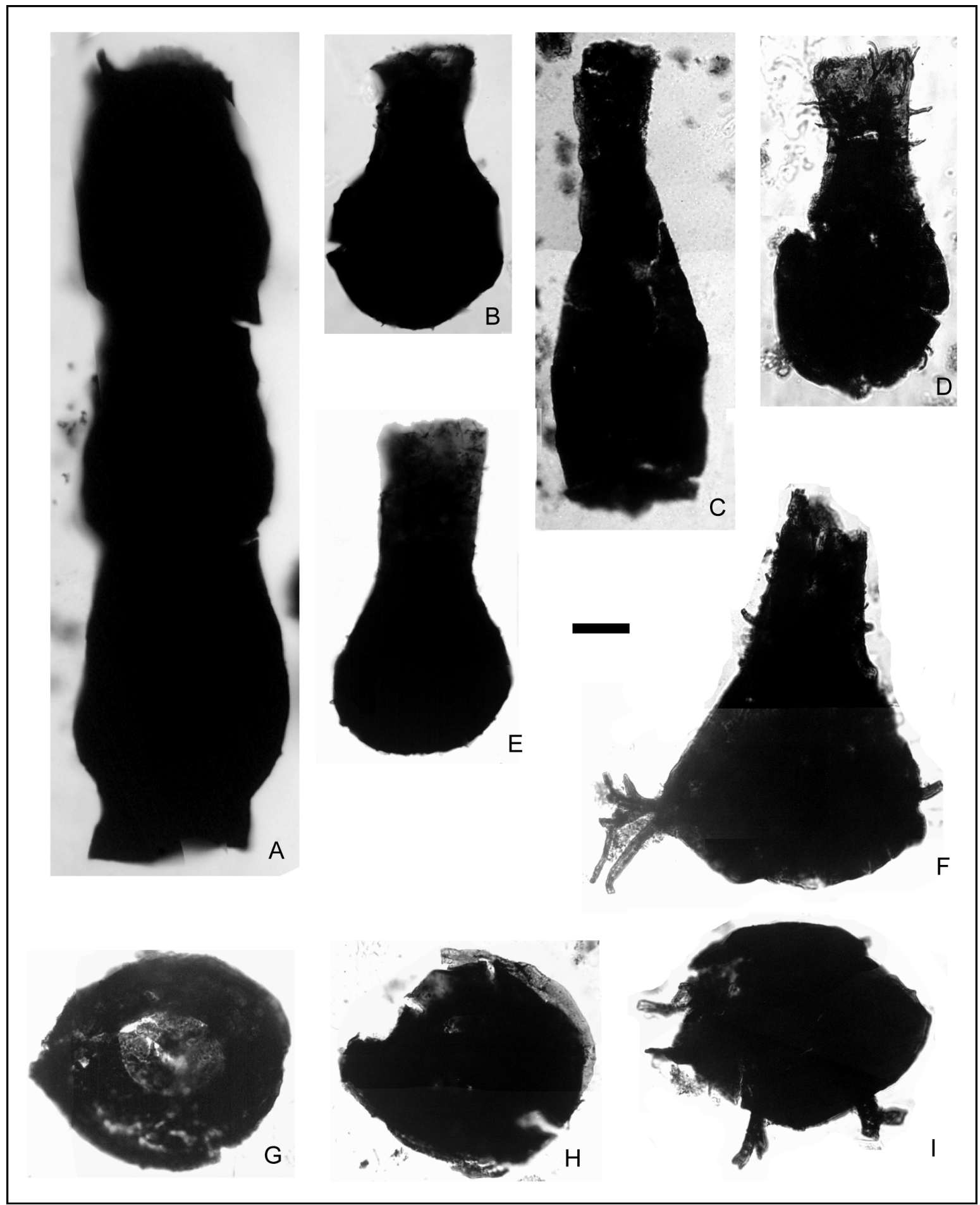

Figure 5. A, Cingulochitina sp. cf. C. serrata (BAFC-PI 2088(1), EF: G55); B, Angochitina sp. (BAFC-PI 2087(1), EF: E57/3); C, ?Angochitina filosa (BAFC-PI 2090(1), EF: S34/3); D, ?Angochitina filosa (BAFC-PI 2089(1), EF: B28/3); E, ?Angochitina chlupaci (BAFC-PI 2088(1), EF: Z46/2); F, I, Ancyrochitina sp. cf. A. tomentosa (BAFC-PI 2089(1), EF: H23/4); G, Hoegisphaera sp. cf. H. glabra (BAFC-PI 2088(1), EF: B47/3); H, Pterochitina spp. (BAFC-PI 2088(1), EF: D45). Scale bar $=20 \mu \mathrm{m}$.

\section{ACKNOWLEDGEMENTS}

We acknowledge M.M. Vergel and G. Aceñolaza for having invited us to participate of the field trip and to give in the study of the Devonian rocks of the region. C. Rubinstein and Y. Grahn are gratefully thanked for their careful reviews in order to improve the manuscript. The first author would like to specially thank Stefan Little for checking the English language. Thanks are also given to Gustavo Holfeltz for having processed the samples. This investigation was supported by CONICET PIP 5518, PICTR 0313/01 AGENCIA and UBACyT X428. This paper was a contribution to the XII SBPP (Florianópolis, November 0205th, 2008). 


\section{REFERENCES}

Aceñolaza, F.G.; Aceñolaza, G. \& Garcia, G. 1999. El SilúricoDevónico del Noroeste Argentino. In: Geología Argentina, Buenos Aires, Servicio Geológico Minero Argentino, p. 205214 (Anales 29).

Achab, A. \& Asselin, E. 1993. Upper Silurian and Lower Devonian chitinozoan microfaunas in the Chaleurs Group, Eastern Canada. Special Papers in Palaeontology, 48:7-15.

Achab, A.; Rubinstein, C.V. \& Astini, R.A. 2006. Chitinozoans and acritarchs from the Ordovician perigondwanan volcanic arc of the Famatina System, northwestern Argentina. Review of Palaeobotany and Palynology, 139:129-149.

Burden, E.T.; Nowlan, G.S.; Quinn, L. \& Bailey-Nill, L.A. 2002. Palynology and micropaleontology of the Clam Bank Formation (Lower Devonian) of Western Newfoundland, Canada. Palynology, 26:185-215.

Cuerda, A.A. \& Baldis, B. 1971. Silúrico-Devónico de la Argentina. Ameghiniana, 8:128-164.

Deunff, J. 1976. Les acritarches. In: Les Schistes et Calcaires Eodevoniens de Saint-Cenéré (Massif Armoricain, France): sédimentologie, paleontologie, stratigraphie, Rennes, p. 59-77, pl. 10-16 (Mémoire de la Société géologique et mineralogique de Bretagne 19).

di Pasquo, M.M. 2007. Asociaciones palinológicas en las formaciones Los Monos (Devónico) e Itacua (Carbonífero Inferior) en Balapuca (cuenca Tarija), sur de Bolivia. Parte 1. Formación Los Monos. Revista Geológica de Chile, 34:97-137.

di Pasquo, M.M. \& Vergel, M.M. 2008. Primer registro palinológico del Pennsylvaniano del Norte de la Sierra de Zenta, provincia de Jujuy, Argentina. In: SIMPÓSIO BRASILEIRO DE PALEOBOTÂNICA Y PALINOLOGIA, 12, 2008. Boletim de resumos, Florianópolis, UFRGS/UFSC, p. 51.

Díaz Martínez, E.; Vavrdová, M.; Bek, J. \& Isaacson, P.E. 1999. Late Devonian (Famennian) glaciation in western Gondwana: evidence from the Central Andes. Abhandlungen der Geologischen Bundesanstalt, 54:213-237.

Dufka, P. \& Fatka, O. 1993. Chitinozoans and acritarchs from the Ordovician-Silurian boundary of the Prague Basin, Czech Republic. Special Papers in Palaeontology, 48: 17- 28.

Eisenack, A. 1931. Neue Mikrofossilien des baltischen Silurs 1. Palaeontologische Zeitschrift, 13:74-118.

Eisenack, A. 1937. Neue Mikrofossilien des baltischen Silurs IV. Palaeontologische Zeitschrift, 19: 217-243.

Eisenack, A. 1955. Chitinozoen, Hystrichosphaeren und andere Mikrofossilien aus dem Beyrichia Kalk. Senckenbergiana Lethaea, 36:157-188.

Fatka, O.; Brocke, R. \& Wilde, V. 2003. Organic-walled microfossils at the Silurian/Devonian boundary stratotype (Klonk near Suchomasty, Barrandian area, Czech Republic). In: Proceedings of the 7th International Graptolite Conference \& Field Meeting of the International Subcommission on Silurian Stratigraphy, San Juan, INSUGEO, p. 125-128 (Serie Correlación Geológica 18).

Grahn, Y. 2005. Devonian chitinozoan biozones of Western Gondwana. Acta Geologica Polonica, 55:211-227.

Grahn, Y.; Loboziak, S. \& Melo, J.H.G. 2003. Integrated correlation of Late Silurian (Prídolí s.l.)-Devonian chitinozoans and miospores in the Solimões Basin, northern Brazil. Acta Geologica Polonica, 53(4):283-300.

Haydoutov, I. \& Yanev, S. 1997. The Protomoesian microcontinent of the Balkan Peninsula - a peri-Gondwanaland piece. Tectonophysics, 272:303-313.
Lakova, I. 1993. Biostratigraphy of Lochkovian chitinozoans from north Bulgaria. Special Papers in Palaeontology 48:37-44.

McGregor, D.C.\& Camfield, M. 1976. Upper Silurian? to Middle Devonian spores of the Moose River Basin, Ontario. Ottawa, Geological Survey of Canada, p. 1-63 (Bulletin 263).

McGregor, D.C. \& Camfield, M. 1982. Middle Devonian miospores from the Cape de Bray, Weatherall, and Hecla Bay Formations of northeastern Melville Island, Canadian Arctic. Ottawa, Geological Survey of Canada, p. 1-105 (Bulletin 348).

Nestor, V. 1994. Early Silurian chitinozoans of Estonia and North Latvia. Academia, 4:1-163.

Ottone, E.G. 1996. Devonian palynomorphs from the Los Monos Formation, Tarija Basin, Argentina. Palynology, 20:105-155.

Ottone, E.G. \& Rossello, E.A.1996. Palinomorfos devónicos de la Formación Tequeje, Angosto del Beu, Bolivia. Ameghiniana, 33:443-452.

Padula, E.L.; Rolleri, E.O.; Mingramm, A.; Criado Roque, P.; Flores \& M.A. \& Baldis, B.A. 1967. Devonian of Argentina. In: INTERNATIONAL SYMPOSIUM ON THE DEVONIAN SYSTEM, 2, 1967. Proceedings, Calgary, ASCP, p. 165-199.

Paris, F. 1981. Les Chitinozoaires dans le Paléozoïque du sudouest de l'Europe (cadre géologique-étude systématiquebiostratigraphie). Rennes, Société Géologique et Mineralogique de Bretagne, 492 p. (Mémoire 26).

Paris, F.; Laufeld, S. \& Chlupáè, I. 1981. Chitinizoa of the SilurianDevonian boundary stratotypes in Bohemia. Uppsala, Sveriges Geologiska Undersökning, p. 1-29 (Bulletin 51).

Playford, G. 1977. Lower to Middle Devonian acritarchs of the Moose River Basin, Ontario. Ottawa, Geological Survey of Canada, p. 1-87 (Bulletin 279).

Priewalder,H. 2000. Die stratigraphische Verbreitung der Chitinozoen im Abschnitt Caradoc-Lochkovium des CellonProfils, Karnische Alpen (Kärnten, Österreich). Mitteilungen der Österreichischen Geologischen Gesellschaft, 91:17-29.

Quadros, L.P. 1982. Distribuição bioestratigráfica dos Chitinozoa e Acritarchae na bacia do Parnaíba. Rio de Janeiro, CENPES/ SINTEP, 76 p. (Ciência-Técnica-Petróleo 12).

Staplin, F.L. 1961. Reef-controlled distribution of Devonian microplankton in Alberta. Palaeontology, 4:392-424.

Starck, D. 1995. Silurian-Jurassic stratigraphy and basin evolution of northwestern Argentina. In: Petroleum basins of South America, Tulsa, AAPG, p. 251-267 (Memoir 62).

Starck, D.; Gallardo, E. \& Schulz, A. 1993a . The pre-Carboniferous unconformity in the Argentine portion of the Tarija Basin. In: INTERNATIONAL CONGRESS OF CARBONIFEROUSPERMIAN, 12, 1991. Comptes Rendus, Buenos Aires, vol. 2, p. 373-384.

Starck, D.; Gallardo, E. \& Schulz, A. 1993b. Neopaleozoic stratigraphy of the Sierras Subandinas Occidentales and Cordillera Oriental, Argentina. In: INTERNATIONAL CONGRESS OF CARBONIFEROUS-PERMIAN, 12, 1991. Comptes Rendus, Buenos Aires, vol. 2, p. 353372.

Starck, D. 1999. Facies continentales en el Siluro-Devónico de la cuenca del Noroeste. Provincia de Salta, Argentina. Boletín de Informaciones Petroleras, 16: 99-107.

Steemans, P.; Le Hérissé, A \& Bozdogan, N. 1996. Ordovician and Silurian cryptospores and miospores from Southeastern Turkey. Review of Palaeobotany and Palynology, 93:35-76.

Ströther, P.K. 1991. A classification schema for the cryptospores. Palynology, 15:219-236.

Taugourdeau, P. \& de Jekhowsky, B. 1960. Répartition et description des chitinozoaires Siluro-Dévoniens de quelques sondages de 
la C.R.E.P.S., de la C.F.P.A. et de la S.N. Repal au Sahara. Revue de l'Institut Français du Pétrole, 15:1199-1260.

Turner, J.C.M. 1972. Puna. In: A.F. Leanza (ed.) Geología Regional Argentina, Academia Nacional de Ciencias, p. 91-116.

Utting, J. \& Wielens, H. 1992. Organic petrology, thermal maturity, geology, and petroleum source rock potential of Lower Permian coal, Karoo Supersystem, Zambia. Energy Sources, 14:337-354.

Vaida, M. \& Verniers, J. 2005. Biostratigraphy and palaeogeography of Lower Devonian chitinozoans, from East and West Moesia, Romania. Geologica Belgica, 8:121-130.

Vaida, M. \& Verniers, J. 2006. Chitinozoan implications in the palaeogeography of the East Moesia, Romania. Palaeogeography, Palaeoclimatology, Palaeoecology, 241:561571.

Vergel, M.M.; di Pasquo, M.; Noetinger, S.; Aráoz, L. \& Aceñolaza,
G.F. 2008a. Estudios palinoestratigráficos del Paleozoico en la Sierra de Zenta, Provincia de Jujuy, Argentina: In: JORNADAS GEOLÓGICAS, 2, 2008. Resúmenes, San Miguel de Tucumán, Fundación Miguel Lillo, p. 152- 154.

Vergel, M.M.; di Pasquo, M.M.; Aráoz, L. \& Noetinger, S. 2008 b. Asociaciones palinológicas del Paleozoico en la Sierra de Zenta, provincia de Jujuy, Argentina. In: SIMPÓSIO BRASILEIRO DE PALEOBOTÂNICA Y PALINOLOGIA, 12, 2008. Boletín de resumos, Florianópolis, UFRGS/UFSC, p. 227.

Wicander, E.R. \& Wood, G.D. 1981. Systematics and biostratigraphy of the organic-walled microphytoplankton from the Middle Devonian (Givetian) Silica Formation, Ohio, USA. Pittsburgh, AASP, p. 1-137 (Contribution Series 8).

Received in December, 2008; accepted in January, 2010.

Appendix 1. The species herein identified are reported in the following list by major groups and alphabetical order. Remarks are included when necessary. Some illustrated specimens are grouped at generic level due to their poor preservation which prevents a more specific assignment. Nevertheless, they are included in the stratigraphic distribution of the assemblages, and are figured together with the rest of the species as indicated in brackets (Figures 3, 4, 5).

\section{Phytoplankton}

Ammonidium garrasinoi Ottone, 1996 (Figure 4A)

Baltisphaeridium? sp. (Figure 4B). Remarks: Baltisphaeridium? sp. resembles Baltisphaeridium sp. (in Quadros, 1982, pl. 4, fig. 6), although the former bears shorter processes. Elektoriskos sp. A (in Wicander \& Wood, 1981) has longer and more numerous processes. Dictyotidium variatum Playford, 1977 (Figure 4C )

Exochoderma arca Wicander \& Wood, 1981 (Figure 4D)

Leiosphaeridia sp. (Figure 4E)

Multiplicisphaeridium ramusculosum Deunff, 1976 (Figure 4F)

?Multiplicisphaeridium sp. (Figure 4G). Remarks: the specimen resembles Multiplicisphaeridium cf. robertinum (in Dufka \& Fatka, 1993), but the poor preservation prevents a more accurate determination.

Quadrisporites granulatus (Cramer) Ströther, 1991 (Figure 4H)

Quadrisporites variabilis (Cramer) Ottone \& Rosello, 1996 (Figure 4I)

Veryhachium sp. (Figure 4J)

\section{Incertae sedis}

?Algal coenobium A (Figure 4K)

Algal coenobium B (Figure 4L). Remarks: this specimen resembles Algal coenobium (in Díaz Martínez et al. 1999, pl. 4, fig. 3) from the Villa Molino section, Bolivia (Devonian-Carboniferous transition).

\section{Spores and cryptospores}

Ambitisporites avitus/dilutus morphon Steemans, Le Hérissé \& Bozdogan, 1996 (Figure 4M)

Apiculatasporites sp. (Figure 4N)

Apiculiretusispora sp. (Figure 4O)

Cymbosporites sp. (Figure 4P)

Dibolisporites farraginis McGregor \& Camfield, 1982 (Figure 4Q)

Dyadospora sp. (Figure 4R)

Retusotriletes sp. (Figure 4S)

Retusotriletes sp. cf. R. maculatus McGregor \& Camfield, 1976 (Figure 4T)

?Scylaspora costulosa Breuer, Al-Ghazi, Al-Ruwaili, Higgs, Steemans \& Wellman (Figure 4U)

\section{Chitinozoans}

Ancyrochitina sp. cf. A. tomentosa Taugourdeau \& de Jekhowsky, 1960 (Figure 5F, I)

?Angochitina chlupaci Paris \& Laufeld, 1981 (in Paris, Laufeld \& Chlupáè, 1981 sensu Burden et al. (2002) (Figure 5E)

?Angochitina filosa Eisenack, 1955 (Figures 5C-D)

Angochitina sp. (Figure 5B)

Cingulochitina sp. cf. C. serrata Taugourdeau \& de Jekhowsky, 1960 (Figure 5A)

Hoegisphaera sp. cf. H. glabra Staplin, 1961 (Figure 5G)

Pterochitina spp. (Figure 5H). Remarks: some specimens herein identified look similar to Pterochitina sp. (in Achab \& Asselin, 1993) while others resemble Pterospermella sp. (in Achab et al. 2006, pl. 1, fig. 22), but the latter one is smaller. Pterochitina perivelata Eisenack 1937 has a much wider flange and Pterochitina makroptera Eisenack (in Nestor, 1994) is bigger. 